\title{
Kekuatan Modal Sosial dan Keberhasilan Gerakan Sayang Ibu \\ (Belajar dari Pengalaman Gampong Tibang-Kota Banda Aceh \\ Dalam Mengupayakan Persalinan Aman Bagi Ibu Hamil)
}

\begin{abstract}
Masrizal $^{1}$
Abstract

This paper describes how Gampong Tibang, a coastal settlement severely damaged by the tsunami in 2004 with programs Loving Mother Movement (GSI) is integrated between the community and the government in improving the quality of life of women with a variety of activities having an impact on efforts to reduce mortality mothers due to pregnancy, childbirth, and the postpartum and infant mortality rate in view of the cases are still found in society. The approach in this study is qualitative with data collection techniques through observation, interviews, focus group discussions, and documentation. The findings of this research is the GSI program implemented by the government of the city of Banda Aceh, through the Department of Health in this regard by training cadres Posyandu health centers as a key actor village level. The program aims to address a variety of health problems experienced by pregnant mothers, giving stimulants to family and society and thus creating a more hospitable environment for pregnant and lactating mothers. The approach used is to improve the understanding of the family and the community through mentoring and counseling activities and create the environment conscious, responsive and able to prevent and overcome the various problems faced by pregnant women to exploit the potential of the local community. Residents are also trained to be ready under any circumstances stand to give first aid for pregnant women. For this purpose, a series of activities such as data collection pregnant women do and then to pregnant mothers are given identification card/specific reference to the condition of the pregnant mother so that people can easily know it. Likewise, for the people who have volunteered their car as "ambulance village" that used to transport pregnant women to the hospital/clinic or to the other treatment when undergoing the process of childbirth. To ease the labor process, labor costs to be repaid through Tabungan Ibu Bersalin (Tabulin). If there are people who have not been able to repay will be bailed out. Bailed out funds was taken from the Tabulin of other mothers. The pregnant women in the village were examined periodically by a midwife. The program is also reinforced with a variety of other activities to support the safe delivery for mothers with community-based (local wisdom).
\end{abstract}

Keyword: Loving Mother Movement, Local Wisdom, Social Capital

${ }^{1}$ Dosen Sosiologi Fakultas Ilmu Sosial dan Ilmu Politik Universitas Syiah Kuala, Mahasiswa Doktoral Program Studi Sosiologi Fakultas Ilmu Sosial dan Ilmu Politik Universitas Gadjah Mada Yogyakarta. 


\section{Pendahuluan}

Sekitar setengah juta warga dunia meninggal akibat persalinan ibu hamil setiap tahunnya, sebagian terbesar berada di wilayah negara berkembang seperti Indonesia. Tak mengherankan jika masyarakat internasional kemudian menaruh perhatian besar melalui berbagai program, seperti Menciptakan Kehamilan yang Lebih Aman (Making Pregnancy Safer Program) yang dilaksanakan oleh World Health Organisation (WHO). Dalam hal ini pemerintah Indonesia tidak tinggal diam. Menindaklanjuti salah satu rekomendasi dari konferensi internasional kesehatan dunia, Internasional Conference on Population and Development, di Mesir, Kairo, tahun 1994 dan the World Conference on Women, di Beijing, 1995, Indonesia kemudian menginisiasi program Gerakan Sayang Ibu [(GSI) Safe Motherhood Program]. (Rahima, 2005).

Awal dari kemunculan Gerakan Sayang Ibu ini tepat pada puncak acara peringatan Hari Ibu pada tahun 1996. Acara tersebut diadakan di Desa Jaten, Karanganyar, tempat kelahiran Mantan Ibu Negara, (alm) Ibu Tien Soeharto. Pada kesempatan itu Presiden Soeharto meluncurkan Gerakan Sayang Ibu, yang tujuannya mempercepat penurunan angka kematian ibu (AKI). Sebelumnya, pada 19-21 Juni 1996, diadakan Lokakarya Penurunan Angka Kematian Ibu di Jakarta. Di situ Presiden menekankan perlunya percepatan penurunan AKI.

Pada perjalanannya program ini ternyata justru semakin meredup dari pada sebaliknya. Pelaksanaan otonomi daerah yang memberikan keleluasaan bagi pemda untuk mengembangkan pemerintahannya secara mandiri ditengarai menjadi salah satu penyebab menurunnya pamor agenda-agenda sentralistik dari tingkat nasional. Merespon hal tersebut, kemudian Ibu Negara Ani Yudhono melakukan pencanangan revitalisasi GSI, pada tanggal 19 April 2007 di Karawang, Jawa Barat. Tujuannya masih tetap sama yaitu penurunan AKI dan Angka kematian bayi (AKB).

AKI sendiri merupakan salah satu indikator untuk melihat derajat kesehatan perempuan. Angka kematian ibu juga merupakan salah satu target yang dituangkan dalam Tujuan Pembangunan Milennium [Millenium Development Goals (MDGs)], lebih spesifik, yaitu tujuan ke 5: meningkatkan kesehatan ibu dengan target yang akan dicapai sampai tahun 2015 adalah mengurangi sampai 3/4 resiko jumlah kematian ibu. Dari hasil survei yang dilakukan AKI telah menunjukkan penurunan dari waktu ke waktu, namun demikian upaya untuk mewujudkan target tujuan pembangunan milenium masih membutuhkan komitmen dan usaha keras yang terus menerus.

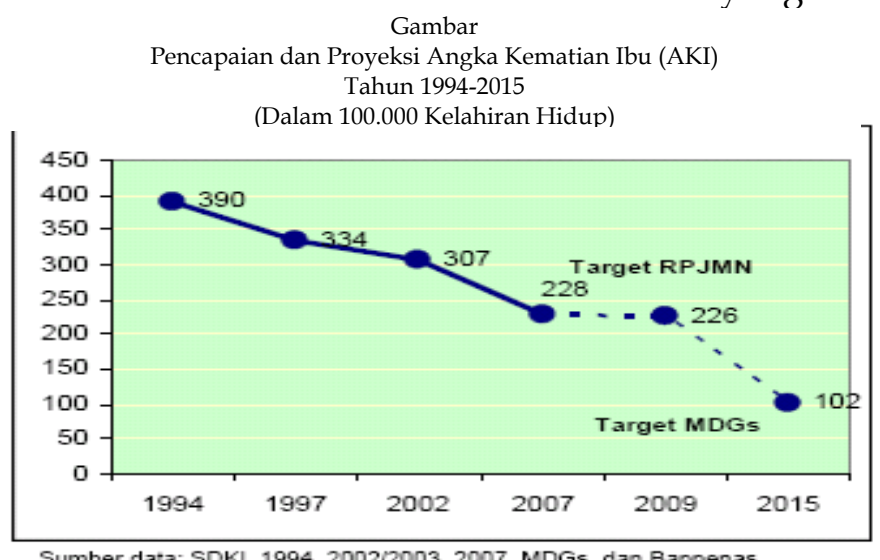


Gambar di atas menunjukkan trend AKI Indonesia secara Nasional dari tahun 1994 sampai dengan tahun 2007, dimana menunjukkan penurunan yang signifikan dari tahun ke tahun. Berdasarkan SDKI survei terakhir tahun 2007 AKI Indonesia sebesar 228 per 100.000 Kelahiran Hidup, meskipun demikian angka tersebut masih tertinggi di Asia. Sementara target Rencana Pembangunan Jangka Menengah Nasional (RPJMN) adalah sebesar 226 per 100.000 Kelahiran Hidup.

Rendahnya kesadaran masyarakat tentang kesehatan ibu hamil menjadi factor penentu angka kematian. Beberapa penyebab tidak langsung dari tingginya AKI adalah:

a. Rendahnya pendidikan para ibu yang mengakibatkan kurangnya kesadaran perawatan kesehatan pada saat kehamilan. Sejumlah indikasi yang seringkali muncul terkait dengan kematian ibu antara lain: pendarahan, keracunan kehamilan yang disertai kejangkejang, aborsi, dan infeksi.
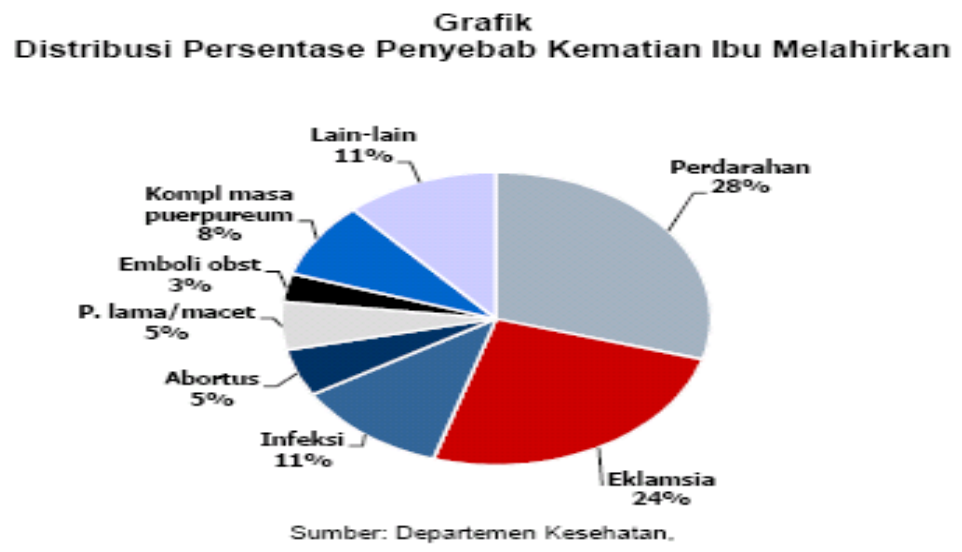

b. Rendahnya kapasitas ekonomi keluarga yang berdampak misalnya pada status gizi buruk serta prevalensi anemi ibu hamil yang tinggi;

c. Kebiasaan masyarakat yang kontraproduktif bagi penurunan AKI, diantaranya ketidakpekaan laki-laki dalam keluarga menyangkut persoalan kehamilan dan persalinan, kebiasaan menikah dan hamil di usia muda, hamil di usia senja, terlalu banyak anak, maupun terlalu pendeknya rentang usia kelahiran. Karenanya kaum lelaki pun kemudian dituntut berupaya ikut aktif dalam segala permasalahan bidang reproduksi secara lebih bertanggung jawab. Oleh karena itu, pandangan yang menganggap kehamilan adalah peristiwa alamiah perlu diubah secara sosiokultural agar perempuan dapat perhatian dari masyarakat. Sangat diperlukan upaya peningkatan pelayanan perawatan ibu selain oleh pemerintah, swasta, namun justru yang terdekat yaitu lingkungan sekitar, keluarga, dan terutama suami;

d. Rendahnya akses pelayanan perawatan persalinan yang memadaikhususnya karena persoalan geografis;

e. Minimnya kualitas sarana-prasarana penunjang;

f. Rendahnya cakupan pertolongan oleh tenaga kesehatan. Departemen Kesehatan menetapkan target 90 persen persalinan ditolong oleh tenaga medis pada tahun 2010. 


\section{Gambar}

Presentase Kelahiran Yang Dibantu Oleh Tenaga Kesehatan dan Target Nasional Tahun 1990-2010

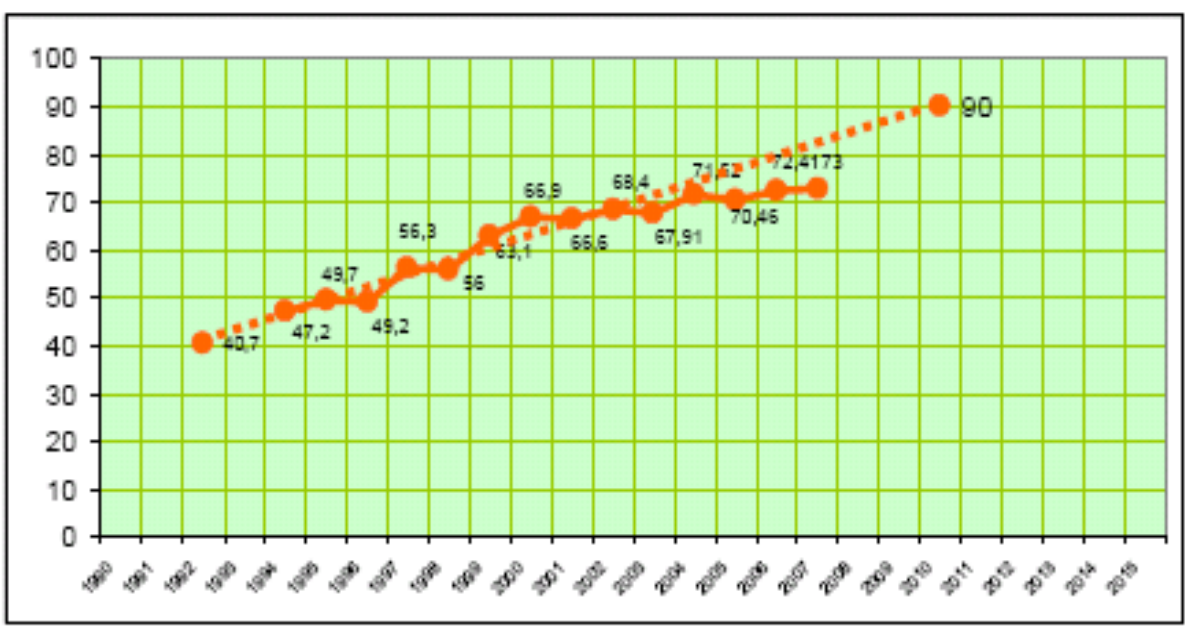

Sumber data: Departemen Kesehatan, R.I, 2007

Perbandingan dengan hasil survei SDKI bahwa persalinan yang ditolong oleh tenaga medis profesional meningkat dari 66 persen dalam SDKI 2002-2003 menjadi 73 persen dalam SDKI 2007. Angka ini relatif rendah apabila dibandingkan dengan negara tetangga seperti Singapura, Malaysia, Thailand di mana angka pertolongan persalinan oleh tenaga kesehatan hampir mencapai 90\%;

\section{Grafik}

Tempat Persalinan dan Penolong Persalinan dengan Kualifikasi Terendah

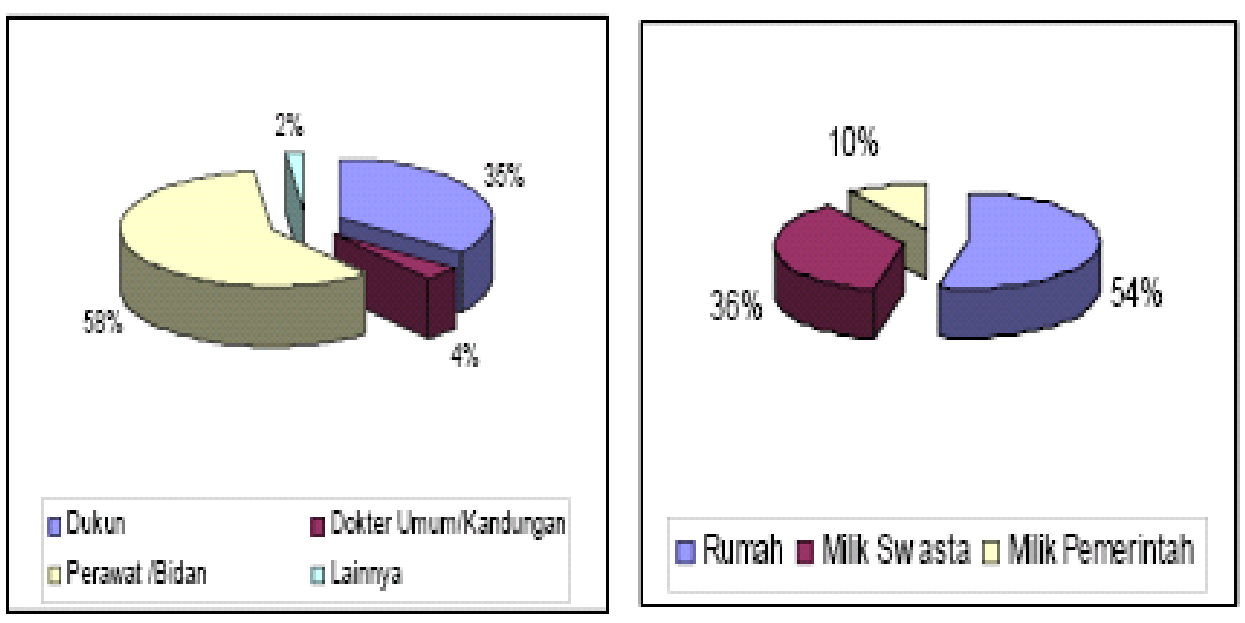

Sumber : SDKI 2007 


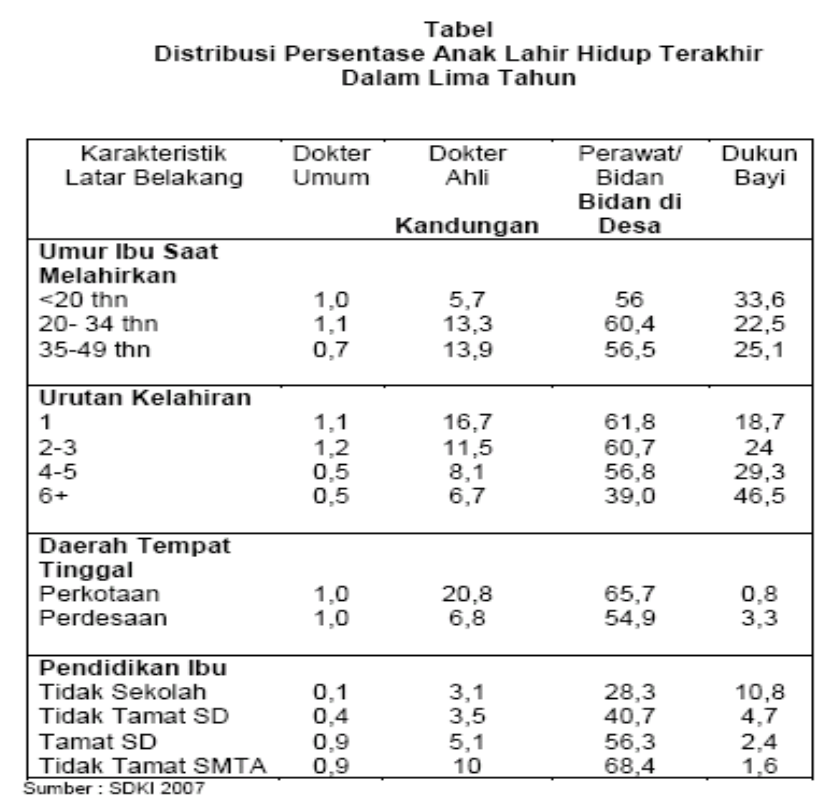

g. Lemahnya regulasi pemerintah pada isu ini. Dengan demikian, perhatian terhadap ibu khususnya ibu hamil merupakan langkah preventif untuk menekan AKI. Oleh sebab itu, dengan adanya program seperti gerakan sayang ibu (GSI) ini jargon "Ibu Sehat, Anak Sehat, Bangsa Kuat" yang telah dicanangkan diharapkan dapat terwujud.

\section{Tinjauan Pustaka dan Kerangka Teori}

Pendekatan teori yang digunakan dalam kajian Gerakan sayang Ibu berbasis gerakan masyarakat ini melihat kepada teori tindakan sosial dalam kajian sosiologi dengan pendekatan konsep penggorganisasian masyarakat dan konsep modal sosial atau kearifan lokal yang tumbuh dikalangan masyarakat.

\section{a. Penggorganisasian Masyarakat}

Pengorganisasian masyarakat dapat dijelaskan sebagai suatu upaya masyarakat untuk saling mengatur dalam mengelola kegiatan atau program yang dikembangkan dengan membentuk panitia kerja, melakukan pembagian tugas, saling mengawasi, merencanakan kegiatan dan lain-lain. Pengorganisasian masyarakat atau pengembangan masyarakat memiliki fokus terhadap upaya menolong anggota masyarakat yang memiliki kesamaan minat untuk bekerja sama, mengidentifikasi kebutuhan bersama dan kemudian melakukan kegiatan bersama untuk memenuhi kebutuhan tersebut. PM seringkali diimplementasikan dalam bentuk (a) proyekproyek pembangunan yang memungkinkan anggota masyarakat memperoleh dukungan dalam memenuhi kebutuhannya atau melalui (b) kampanye dan aksi sosial yang memungkinkan kebutuhan-kebutuhan tersebut dapat dipenuhi oleh pihak-pihak lain yang bertanggungjawab (Payne, 1995:165). Pemahaman Payne ini jika dikaitkan dengan pola gerakan Sayag Ibu yang diperankan oleh stakeholder di Gampong Tibang, Dinas kesehatan dan Inisiasi yang dilahirkan oleh Walikota Banda Aceh merupakan suatu perwujudan menjawab program MDGs yang sedang dikembangkan di Indonesia. Sehingga pola kerja yang dilakukan menjadi salahsatu upaya dalam 
menolong dan menekan minimnya terjadi AKI dan AKB di Kota Banda Aceh umumnya dan spesifik gampong Tibang Kota Banda Aceh.

\section{b. Modal Sosial}

Modal sosial merupakan kemampuan masyarakat untuk bekerja sama demi mencapai tujuan bersama di dalam berbagai kelompok dan organisasi. Bourdieu, menyatakan ada tiga macam modal, yaitu modal uang, modal sosial, dan modal budaya, dan akan lebih efektif digunakan jika di antara ketiganya ada interaksi sosial atau hubungan sosial. Modal sosial dapat digunakan untuk segala kepentingan, namun tanpa ada sumber daya fisik dan pengetahuan budaya yang dimiliki, maka akan sulit bagi individu-individu untuk membangun sebuah hubungan sosial. Hubungan sosial hanya akan kuat jika ketiga unsur di atas eksis (Hasbullah, 2004:9).

Sedangkan dalam pandangan Putnam (1993) dalam Jhon Field, modal sosial sebagai suatu nilai mutual trust (kepercayaan) antara anggota masyarakat dan masyarakat terhadap pemimpinnya. Modal sosial didefinisikan sebagai institusi sosial yang melibatkan jaringan (networks), norma-norma (norms), dan kepercayaan sosial (social trust) yang mendorong pada sebuah kolaborasi sosial (koordinasi dan kooperasi) untuk kepentingan bersama. Hal ini juga mengandung pengertian bahwa diperlukan adanya suatu sosial networks (networks of civic engagement) atau ikatan/jaringan sosial yang ada dalam masyarakat, dan norma yang mendorong produktivitas komunitas. Bahkan lebih jauh Putnam mengutarakan pemaknaan asosiasi horisontal, tidak hanya yang memberi desireable outcome (hasil pendapatan yang diharapkan) melainkan juga undesirable outcome (hasil tambahan). Putnam merumuskan modal sosial dengan mengacu pada ciri-ciri organisasi sosial, seperti jaringan, norma-norma, dan kepercayaan yang memfasilitasi koordinasi kerja sama untuk sesuatu yang manfaatnya bisa dirasakan secara bersama-sama (mutual benafit).

\section{Temuan dan Pembahasan}

\subsection{Sekilas Gampong Tibang}

Gampong Tibang terletak di pesisir Kota Banda Aceh, termasuk dalam wilayah administrative kecamatan Syiah Kuala. Gampong yang terdiri dari 3 dusun, yakni: Tgk. Meulagu, Tgk. Meurah, dan Meulinje, ini dipimpin oleh Geuchik (kepala desa) bernama Mahyuddin Makkam. Jumlah penduduk di gampong ini berkisar 1440 orang dengan jumlah KK sebanyak 440. Sebagian terbesar penduduk bekerja sebagai petani. Mobilitas penduduk relatif rendah. Walau berada di ibukota propinsi, namun tak banyak penduduk yang masuk, dan tak banyak pula yang keluar dari Gampong Tibang ini. Mayoritas adalah etnis setempat, meskipunpun ada pula beberapa yang lain khususnya dari etnis Jawa, Sunda, dan Batak, sebagai perantauan pasca tsunami.

Terkait dengan sarana dan prasarana fisik yang menunjang kehidupan penduduk, hampir semua tersedia: sekolah, puskesmas pembantu (pustu), sarana peribadatan (masjid), kantor geuchik, jalan yang cukup accessable, jaringan listrik dan komunikasasi tak menjadi kendala berarti. Bahkan di sekitar Gampong ini berdiri juga Universitas dan STIKES Ubudiyah, dimana menjadikan Gampong Tibang sebagai desa binaannya. Di samping itu, pemerintah kota juga mencangkan lahan ratusan hektar yang berada di Gampong Tibang sebagai hutan kota. Selain berorientasi ekologis, pencanangan program yang dilakukan oleh Presiden Susilo Bamabang Yudhoyono itu juga dimaksudkan untuk meningkatkan perekonomian masyarakat. Pemko berharap 
hutan bakau tersebut dapat dimanfaatkan sebagai lahan budidaya ikan, udang, kepiting, dan sebaginya yang memiliki nilai ekonomis. Sebagaimana disebutkan di muka, prestasi membanggakan yang mengangkat nama Gampong ini adalah pencapaiannya dalam menurunkan angka kematin ibu dan bayi melahirkan sampai pada derajat yang terendah yaitu nihil. Meskipun sebagai sebuah program aktivitas peduli ibu ini tergolong baru, namun pada dasarnya ekspresi tersebut sudah lama berkembang di tengah masyarakat dalam wajah informalitas.

\subsubsection{Latar Belakang Program Gerakan Sayang Ibu (GSI)}

GSI adalah sebagai sebuah jargon "Ibu Sehat, Anak Sehat, Bangsa Kuat" yang telah dicanangkan diharapkan dapat terwujud.
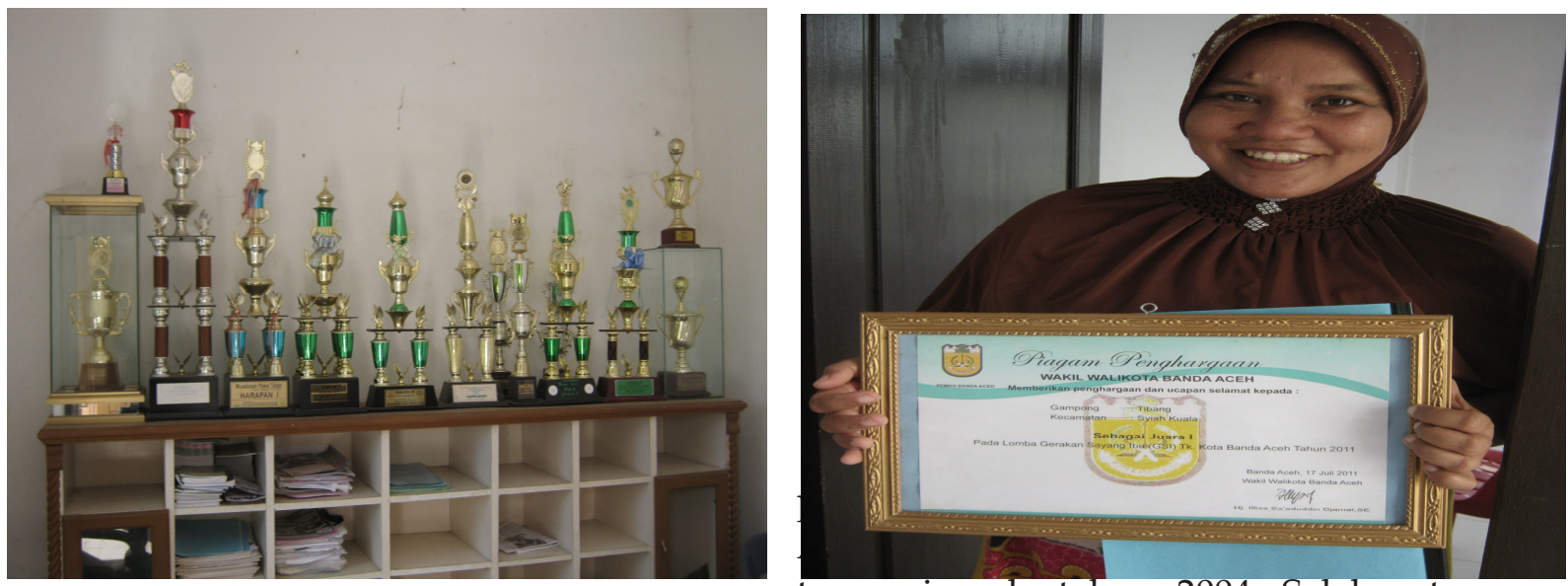

tsunami pada tahun 2004. Salah satu

hal yang menarik dari Gampong ini adalah angka kematian ibu dan bayi melahirkan yang berada pada derajat terendah atau nihil selama lima tahun terakhir. Pencapaian ini kemudian sering dikaitkan dengan program nasional Gerakan Sayang Ibu (GSI), dimana dalam penilaian di tingkat kota, Tibang dikukuhkan sebagai yang terbaik (Juara 2, tahun 2010 dan Juara 1, tahun 2011). Tentu hal ini sebuah prestasi yang menarik untuk dikaji. Harapannya eksplorasi program GSI dari fase inisiasi, implementasi, dan evalusasi yang dilakukan di Tibang dapat menjadi inspirasi bagi daerah lain di Indonesia.

Kota Banda Aceh adalah Ibukota Provinsi Aceh, Dahulu kota ini bernama Kutaraja, kemudian sejak 28 Desember 1962 namanya diganti menjadi Banda Aceh. Berdasarkan naskah tua dan catatan sejarah, Kerajaan Aceh Darussalam dibangun di atas puing-puing kerajaan-kerajaan Hindu dan Budha seperti Kerajaan Indra Purba, Kerajaan Indra Purwa, Kerajaan Indra Patra, dan Kerajaan Indra Pura, dimana Banda Aceh Darussalam sebagai ibukotanya. Hingga tahun 2015, usia Banda Aceh telah menginjak 810 tahun. Tak heran, selain sebagai pusat pemerintahan, kota Islam tertua di Asia tenggara ini sejak lama telah memainkan peran sebagai pusat kegiatan ekonomi, politik, sosial, budaya, dan pengembangan pendidikan khususnya Islam di wilayah barat Indonesia.

Pada tanggal 26 Desember 2004, kota ini dilanda gelombang pasang tsunami yang diakibatkan oleh gempa 7,9 Skala Richter di Samudera Indonesia. Bencana ini menelan dua ratu ribu lebih jiwa penduduk, menghancurkan lebih dari $60 \%$ bangunan 
kota, dan menjadi salah satu bencana terhebat dalam dua abad terakhir, dan bahkan lokasi penelitian ini bersih disapu gempa dan gelombang tsunami. Kini Kota Banda Aceh telah pulih kembali, tidak hanya dari efek destruktif tsunami namun juga konflik berkepanjangan antara pemerintah RI dengan GAM melalui perjanjian Helsinkipun telah usai, bertepatan tanggal 15 Agustus 2005. Proses rehabilitasi dan rekonstruksi Banda Aceh dilaksanakan oleh pemerintah pusat melalui Badan Pelaksana Rehabilitasi dan Rekontruksi Aceh dan Nias (BRR), pemerintah kota, maupun bantuan dari badanbadan dunia dan berbagai Negara Donor bersama NGO.

Kota yang dikenal dengan sebutan Serambi Mekkah ini dipimpin oleh Mawardi Nurdin (politisi Partai Demokrat) selaku Walikota berturut-turut dua periode sejak Desember 2007-2012 dan 2012-2017, yang berpasangan dengan Illiza Saaduddin Djamal [Politisi Partai Persatuan Pembangunan (PPP), namun pada tahun 2013 sang walikota pihan warga Kota Banda Aceh tersebut meninggal dunia, dan tampuk kepemimpinan diserahkan ke Ibu Illiza Saaduddin Djamal, SE dengan wakilnya Drs. Zainal Arifin (Politisi PAN).

Luas wilayah Banda Aceh sendiri mencapai $61,36 \mathrm{~km}^{2}$, dengan penduduk berdasarkan hasil Sensus Penduduk (SP) 2010 yang dilakukan oleh BPS-RI berjumlah 223.446 jiwa, terdiri dari 115.098 orang laki-laki dan 108.348 orang perempuan. Secara administrative Kota Banda Aceh terbagi ke dalam 9 kecamatan, 17 mukim, dan 90 gampong (70 desa +20 kelurahan). Dengan demikian terdapat 9 orang camat dan 90 kepala desa (geuchik). Setiap kepala pemerintahan tersebut memiliki wewenang untuk mengatur roda administrasi wilayahnya masing-masing. Kondisi kapasitas fiskal tergolong sedang dimana PAD tahun 2009-2011 berturut-turut sebagai berikut: 50.000.000.000; 52.276.367.773; 57.000.000.000. Dengan kondisi demografi dan perekonomian demikian, persentase penduduk miskin dan garis kemiskinan Kota Banda Aceh dibandingkan dengan Kabupaten/Kota di Aceh lainnya berada pada rating tertinggi:

Tabel Persentase Penduduk Miskin/Garis Kemiskinan Kabupaten/Kota Propinsi Aceh Tahun 2010

\begin{tabular}{|l|l|c|c|}
\hline No. & \multicolumn{1}{|c|}{ Kabupaten/Kota } & $\begin{array}{c}\text { Persentase } \\
\text { Penduchi miskin/ } \\
\text { Percentage of Poor } \\
\text { People }\end{array}$ & $\begin{array}{c}\text { Garis Kemiskinan/ } \\
\text { Poverty Line }\end{array}$ \\
\hline$(1)$ & \multicolumn{1}{|c|}{$(2)$} & $(3)$ & $(4)$ \\
\hline 1 & Simeulue & 23,63 & 278.023 \\
2 & Aceh Singkil & 19,39 & 280.534 \\
3 & Aceh Selatan & 15,93 & 257.640 \\
4 & Aceh Tenggara & 16,79 & 185.626 \\
5 & Aceh Timur & 18,43 & 288.036 \\
6 & Aceh Tengah & 20,1 & 332.598 \\
7 & Aceh Barat & 24,43 & 371.762 \\
8 & Aceh Besar & 18,8 & 324.096 \\
9 & Pidie & 23,8 & 328.337 \\
10 & Bireuen & 19,51 & 263.990 \\
11 & Aceh Utara & 23,43 & 249.824 \\
12 & Aceh Barat Daya & 19,94 & 252.217 \\
13 & Gayo Lues & 23,91 & 253.004 \\
14 & Aceh Tamiang & 17,99 & 298.509 \\
15 & Nagan Raya & 24,07 & 320.490 \\
16 & Aceh Jaya & 20,18 & 267.057 \\
17 & Bener Meriah & 26,23 & 298.798 \\
18 & Pidie Jaya & 26,08 & 337.211 \\
19 & Banda Aceh & 9,19 & 435.195 \\
20 & Sabang & 21,69 & 401.180 \\
21 & Langsa & 15,01 & 270.201 \\
22 & Lhokseumawe & 14,07 & 268.303 \\
23 & Subulussalam & 24,36 & 218.906 \\
& & & \\
\hline Sumber & Susenas 2010 & & \\
& & & \\
\hline
\end{tabular}


Sebagai Ibu Kota Propinsi, tak mengherankan jika capaian kuantitatif penurunan angka kemiskinan di Banda Aceh terbilang berhasil sebagai yang terbaik.

Fasilitas kesehatan dan tenaga kesehatan yang ada di Kota Banda Aceh terbilang memadai. Setiap kecamatan memiliki fasilitas puskesmas dan puskesmas pembantu (pustu). Tenaga kesehatan (tenaga medis) yang paling banyak adalah tenaga perawat dan bidan. Sedangkan tenaga nonmedis yang paling banyak adalah tenaga kesehatan masyarakat. Fasilitas klinik keluarga berencana (KKB) dan pos pelayanan keluarga berencana desa (PPKBD) sudah hampir dimiliki semua desa di kota Banda Aceh. Berikut adalah data kuantitatif kesehatan secara lebih terperinci:

Banyaknya fasilitas Kesehetan di Kota Banda Aceh Tahun 2010

\begin{tabular}{|c|c|c|c|c|}
\hline Tahun & $\begin{array}{c}\text { Rumah Sakit } \\
\text { (umum+swasta) }\end{array}$ & $\begin{array}{c}\text { Rumah } \\
\text { Bersalin }\end{array}$ & Puskesmas & $\begin{array}{c}\text { Puskesmas } \\
\text { Pembantu }\end{array}$ \\
\hline$(1)$ & $(2)$ & $(3)$ & $(4)$ & $(5)$ \\
\hline 2006 & 11 & 12 & 10 & 14 \\
2007 & 11 & 9 & 10 & 15 \\
2008 & 13 & 12 & 11 & 24 \\
2009 & 14 & - & 11 & 25 \\
2010 & 16 & 12 & 11 & 25 \\
\hline
\end{tabular}

\begin{tabular}{|c|c|c|c|c|}
\hline Tahun & $\begin{array}{c}\text { Polindes } / \\
\text { Poskesdes }\end{array}$ & Posyandu & $\begin{array}{c}\text { Klinik/ Balai } \\
\text { Kesehatan }\end{array}$ & $\begin{array}{c}\text { Puskesmas } \\
\text { Keliling }\end{array}$ \\
\hline$(1)$ & $(6)$ & $(7)$ & $(8)$ & $(9)$ \\
\hline 2006 & 16 & 103 & - & 10 \\
2007 & 16 & 110 & - & 10 \\
2008 & 33 & 112 & 18 & 20 \\
2009 & 34 & 112 & - & 19 \\
2010 & 34 & 112 & 3 & 18 \\
\hline
\end{tabular}

Banyaknya Tenaga Kesehatan Menurut Unit Kerja dan Sarana Pelayanan Kesehatasn di Kota Banda Aceh, Tahun 2010

\begin{tabular}{|l|c|c|c|}
\hline \multirow{2}{*}{\multicolumn{1}{|c|}{ Unit Kerja }} & \multicolumn{3}{|c|}{ Tenaga Medis } \\
\cline { 2 - 4 }$(1)$ & Dokter & Perawat \& Bidan & Perawat Gigi \\
\hline \multirow{2}{*}{ Nama Puskesmas } & & & $(3)$ \\
1. Banda Raya & 3 & 25 & \\
2. Ulee Kareng & 4 & 27 & 2 \\
3. Kopelma Darussalam & 3 & 24 & 4 \\
4. Kuta alam & 4 & 21 & 2 \\
5. Meuraxa & 3 & 25 & 2 \\
6. Batoh & 3 & 22 & 4 \\
7. Baiturrahman & 2 & 24 & 2 \\
8. Lampulo & 3 & 13 & 3 \\
9. Lampaseh & 4 & 22 & 2 \\
10. Lampoh Daya & 2 & 27 & 1 \\
11. Jeulingke & 3 & 14 & 2 \\
\hline Sub jumlah (puskesmas) & 34 & 244 & 25 \\
\hline Rumah Sakit: & & & \\
BLuD RSUD Meuraxa & 38 & $\mathbf{4 0 1}$ & - \\
\hline \multicolumn{1}{|c|}{ Jumlah } & $\mathbf{7 2}$ & & \\
\hline
\end{tabular}

\begin{tabular}{|c|c|c|c|c|c|}
\hline \multirow[b]{2}{*}{ Unit Kerja } & \multicolumn{5}{|c|}{ Tenaga NonMedis } \\
\hline & Farmasi & $\begin{array}{l}\text { Ahli } \\
\text { Gízi }\end{array}$ & $\begin{array}{l}\text { Teknisi } \\
\text { Medis') }\end{array}$ & Sanitasi & $\begin{array}{c}\text { Kesehatan } \\
\text { Masyarakat }\end{array}$ \\
\hline (1) & (5) & (6) & (7) & (8) & (9) \\
\hline Nama Puskesmas & & & & & \\
\hline 1. Banda Raya & 2 & 4 & 0 & 0 & 6 \\
\hline 2. Ulee Kareng & 3 & 2 & 0 & 1 & 2 \\
\hline 3. Kopelma Darussalam & 0 & 1 & 1 & 1 & 8 \\
\hline 4. Kuta alam & 2 & 1 & 0 & 3 & 6 \\
\hline 5. Meuraxa & 1 & 2 & 0 & 0 & 1 \\
\hline 6. Batoh & 2 & 0 & 0 & 3 & 1 \\
\hline 7. Baiturrahman & 2 & 0 & 0 & 2 & 4 \\
\hline 8. Lampulo & 1 & 1 & 1 & 1 & 1 \\
\hline 9. Lampaseh & 2 & 1 & 1 & 0 & 4 \\
\hline 10. Lampoh Daya & 1 & 1 & 0 & 0 & 2 \\
\hline 11. Jeulingke & 2 & 1 & 0 & 2 & 2 \\
\hline Sub jumlah (puskesmas) & 18 & 14 & 3 & 13 & 37 \\
\hline $\begin{array}{l}\text { Rumah Sakit: } \\
\text { BLUD RSUD Meuraxa }\end{array}$ & 34 & - & 41 & 7 & 17 \\
\hline Jumlah & 52 & 14 & 44 & 20 & 54 \\
\hline
\end{tabular}


Jumlah Pasangan Usia Subur menurut Kecamatan Kota Banda Aceh Tahun 2010

\begin{tabular}{|c|c|c|}
\hline no & $\begin{array}{l}\text { Kecamatan' } \\
\text { District }\end{array}$ & $\begin{array}{l}\text { Pasarngan Usia Subur } \\
\text { Fertile Age Couple }\end{array}$ \\
\hline (1) & (2) & (3) \\
\hline 1 & Meuraxa & 2.419 \\
\hline 2 & Jaya Baru & 2.839 \\
\hline 3 & Banda Raya & 2.801 \\
\hline 4 & Baiturrahman & 3.526 \\
\hline 5 & Lueng Bata & 2.456 \\
\hline 6 & Kuta Alam & 7.273 \\
\hline 7 & Kuta Raja & 1.221 \\
\hline 8 & Syiah Kuala & 3.308 \\
\hline 9 & Ulee Kareng & 2.703 \\
\hline & $\begin{array}{c}\text { Jumlah/Total } \\
\mathbf{2 0 1 0} \\
2009 \\
2008\end{array}$ & $\begin{array}{l}\mathbf{2 8 . 5 4 6} \\
27.8667 \\
25.061\end{array}$ \\
\hline
\end{tabular}

\subsubsection{Tahap Inisiasi Program Aki (Angka Kematian Ibu)}

a. Inisiasi Program di Tingkat Nasional

Berangkat dari seruan global untuk mengupayakan penurunan AKI, GSI kemudian secara intensif dan ekstensif diselenggarakan di seluruh Indonesia. Dasar hukum yang memperkuat program ini dirujuk dari:

1. Undang-Undang Nomor 7 Tahun 1984, tentang Pengesahan Konvensi Mengenai Penghapusan segala bentuk Diskriminasi terhadap Perempuan; serta

2. Kesepakatan Menteri Koordinasi Kesejahteraan Rakyat, Menteri Kesehatan, Menteri Negara Pemberdayaan Perempuan pada tanggal 12 Maret 2002.

3. Peraturan Menteri negara Pemberdayaan Perempuan Nomor 2 Tahun 2007 tentang Pedoman Umum Pelaksanaan Revitalisasi gerakan Sayang Ibu (GSI) dalam Rangka Percepatan Penurunan Angka Kematian Ibu Karena Hamil, Melahirkan, dan Nifas serta Angka Kematian Bayi di Daerah;

4. Surat keputusan Menetri Negara Pemberdayaan perempuan Nomor 28/SK/MEN.PP/V/2007 tanggal 30 Mei 2007 tentang pembentukan kelompok kerja Tetap gerakan Sayang Ibu;

5. Surat Edaran Meneteri dalam Negeri Nomor 411/2772/SJ tanggal 15 november 2006 tentang pelaksanaan gerakan Sayang Ibu;

6. Surat Menteri Dalam Negeri No.411.2/2765/PMD tanggal 27 Agustus 2008 tentang Revitalisasi Gerakan Sayang ibu.

Realisasinya di lapangan, setiap daerah memiliki variasi alternatif pemecahan masalah yang berbeda-beda. Untuk itu jenis-jenis intervensi yang dilakukan disesuaikan dengan kondisi sosial-budaya, ekonomi, tingkat pendidikan keluarga dan masyarakat, serta mempertimbangkan factor penyebab kematian yang menonjol di daerah tersebut.

Skema kerja GSI menitik beratkan pada sinergitas multi stake-holder antara pemerintah, organisasi kemasyarakatan, organisasi perempuan, organisasi profesi, dan masyarakat secara umum, untuk lebih meningkatkan pengetahuan, kesadaran dan kepedulian kolektif. Disamping itu strategi pemerintah dalam meningkatkan percepatan penurunan angka kematian ibu dan bayi ini juga dilakukan melalui program advokasi, Komunikasi, Informasi dan Edukasi (KIE) bagi bidan, LPM, PKK, 
PLKB, tokoh masyarakat dan tokoh agama dalam pendataan ibu hamil serta pengembangan rujukan oleh masyarakat serta peningkatan kualitas kesehatan kepada masyarakat. Disamping ada format "SIAGA" (siap, antar, jaga), oleh pemerintah juga telah dikembangkan P4K (Program Perencanaan Persalinan dan Pencegahan Komplikasi) yang dimaksudkan untuk menuju persalinan yang aman dan selamat bagi ibu. Selain itu juga untuk meringankan warga dalam hal pembayaran, biaya persalinan tersebut dicicil melalui tabungan ibu bersalin (tabulin). Cicilan dibayar sejak seorang ibu positif hamil sampai tiba saatnya melahirkan. Besar cicilan disesuaikan kemampuan masing-masing keluarga. Ada yang mencicil Rp 200 seminggu atau lebih. Uang itu disimpan pada bidan desa. Bila saat melahirkan tiba namun tabulin belum mencapai Rp 175.000, ibu bersangkutan boleh mencicil sisa biaya setelah melahirkan.

Menurut Ketua Badan Perwakilan Desa (BPD) warga yang belum sanggup mencicil akan ditalangi. Dana talangan diambil dari tabulin para ibu lain. Para ibu hamil di desa itu juga diperiksa secara periodik (antenatal care) oleh bidan desa. Setiap ibu hamil mendapat kartu hasil pemeriksaannya sesuai dengan status kesehatannya. Misalnya, kartu warna merah untuk ibu hamil yang kondisinya kritis. Kartu kuning untuk ibu hamil yang mempunyai faktor risiko, dan kartu hijau untuk kehamilan normal.

Diharapkan langkah-langkah tersebut merupakan langkah preventif untuk menekan angka kematian ibu. Berikut adalah poin-poin latar belakang pencangan program GSI yang di-release oleh Kementerian Pemberdayaan Perempuan:

Latar Belakang Pencanangan Program GSI

- SDM yang berkualitas sangat menentukan keberhasilan suatu pembangunan

- Pembentuakan kualitas SDM yang berkualitas ditentukan dari janin dalam kandungan, karena perkembangan otak terjadi selama hamil sampai dengan 5 tahun

- Kesehatan Ibu dan Anak factor paling strategis untuk meningkatkan mutu SDM

- Angka Kematian Ibu ( AKI ) karena hamil, bersalin dan nifas di Indonesia tergolong tinggi diantara negara-negara ASEAN

- Tingginya AKI dan AKB di Indonesia memberikan dampak negatif pada berbagai aspek

- Kematian Ibu menyebabkan bayi menjadi piatu yang pada akhirnya akan menyebabkan penurunan kualitas SDM akibatnya kurangnya perhatian, bimbingan dan kasih sayang seorang ibu

Setalah mengetahui latar belakang kemunculan GSI, dapat kita pahami bahwa program ini diinisiasi secara top-down; berawal dari seruan global, diserap ke dalam regulasi nasional, dan kemudian dipraktikkan di tingkat gampong/desa di seluruh kabupaten/kota di Indonesia. Walaupun demikian, ternyata pada pelaksanaannya tidak sepenuhnya berhasil. Berdasarkan penuturan Badrunnisa (3/2/12), Kepala Kantor Pemberdayaan Perempuan dan Keluarga Berencana (KPPKB) Kota Banda Aceh, tak lebih dari 50\% desa seluruh Indonesia yang melaksanakan program ini, dan itu pun tidak banyak yang berkelanjutan. Satu diantara yang sering memperoleh penghargaan terkait evaluasi program ini adalah Gampong Tibang, Kota Banda Aceh.

\section{b. Inisiasi di Tingkat Lokal}


Di lingkup Kota Banda Aceh, tanpa mengecilkan peran aktor yang lain, inisiator utama program GSI ini adalah Wakil Walikota lliza Saaduddin Djamal, Dinas Kesehatan dengan kepalanya dr. Meidia, dan Kepala Kantor Pemberdayaan Perempuan dan Keluarga Berencana dengan pimpinannya Baddrunisa. Secara kebetulan ketiganya adalah perempuan dan dikenal aktif dalam memperjuangkan isuisu keadilan dan kesetaraan gender termasuk isu perempuan di dalamnya. Sebagai dasar penguat dari sisi legal formal, program GSI ini juga di atur melalui regulasi di tingkat propinsi dan kota sebagai berikut:

1. Qanun Aceh nomor 4 tahun 2010 tentang kesehatan

2. Surat kepala Kantor Pemberdayaan perempuan dan Keluarga Berencana Kota Banda Aceh Nomor 415/341/2011 tanggal 30 Maret 2011 tentang Usulan/Penunjukan Desa Binaan terpadu Program Pemberdayaan perempuan tahun 2011.

Sebagaimana info yang peneliti peroleh saat wawancara dengan Elyana, aktivis Gampong Tibang, GSI secara serius mulai digarap sebagai sebuah program di Gampongnya sekitar tahun 2002. Waktu itu Gampong Tibang belum memperoleh prestasi. Dan kemudian terhenti akibat tsunami dan baru berjalan lagi tahun 2007, bertepatan dengan pencanangan revitalisasi GSI di tingkat nasional oleh Ibu Negara.

Elyana, Roslina, Meslidar, Anwar, dan Mahyudin (Geuchik), secara umum ketika diwawancara (1-3/2/12), bersepakat jika tradisi menghormati perempuan khususnya para Ibu telah berkembang sejak lama di Gampong dalam kultur Islam yang pekat ini. "Ada atau tanpa adanya program, setiap ada Ibu yang akan melakukan persalinan mayoritas warga akan membantu dan meberikan perhatian. Kalau kemudian belakangan dimunculkan yang namanya GSI, hal itu yang menjadikannya lebih terorganisir saja. Jadi semuanya lebih jelas. Ada datanya. Semua bisa peroleh informasi dengan mudah", ungkap Mahyudin kepada peneliti (1/2/12). Pendapat itu sendiri, pada kenyataannya memang dapat dibuktikan melalui data AKI yang rendah dan stabil setidaknya selama satu decade terakhir. Inilah penjelas mengapa, GSI bisa dengan mudah diterima dan dikembangkan di Tibang.

\subsubsection{Mobilisasi Penduduk: Bauran Kepemimpinan Karismatik dan Struktur Masyarakat yang Hirarkis}

Jika penelusuran kita lakukan lebih dalam, tidak hanya GSI namun juga ide-ide lain yang coba diinisiasi di Gampong Tibang kebanyakan memperoleh respon positif dari seluruh penduduknya. Hal ini secara umum dapat dibaca karena dua hal: Pertama, kuatnya pengaruh pemimpin yang dalam hal ini dimainkan oleh Geuchik, Mahyudin. Dia adalah penduduk asli Tibang, seorang wirausahawan, yang memiliki pengalaman rantau terbilang 'luar biasa' dibandingkan penduduk lainnya. Mahyudin sempat bermukim dan bekerja selama 3 tahun di Korea Selatan. Dengan modal ekonomi dan karisma yang dimilikinya, Ia menjadi sosok yang begitu dihormati. Apalagi di luar kapasitas personal, posisi Geuchik secara kultural memang memiliki legitimasi yang kuat. Kelebihan lain dari Mahyudin adalah kemampuannya dalam merangkul penduduk khususnya para elit Gampong, seperti imam dan tokoh-tokoh tetua; Kemudian alasan yang kedua, yaitu corak masyarakat yang hirarkis. Dalam struktur masyarakat Tibang, Geuchik berada di puncak piramida kekuasaan dimana relasi yang 
terjalin antara elit dengan penduduk di level grass-root cenderung satu arah (inequal). Elit tak semata-mata menjalankan fungsi sebagai 'penyambung lidah' namun lebih sebagai 'wali amanah'. Mereka yang diberi kepercayaan untuk memperjuangkan kepentingan yang diwakilinya.

Pada poin ini, political will dari elit termasuk Geuchik menjadi demikian vital khsusnya dalam menangkap aspirasi penduduk. Selama ini pembahasan persoalan Gampong lebih sering dilakukan dalam forum-forum informal seperti pengajian rutin dan ronda (jaga malam). Di sanalah masalah diangkat, dicari penyelesaiannya, dan sekaligus disosialisasikan untuk dipraktikkan bersama, seperti halnya GSI.

\subsubsection{TAHAP IMPLEMENTASI GSI}

Mengamati struktur organisasi dari gerakan ini dalam grand-design-nya terbilang cukup kompleks, di mana dari tingkat pusat sampai ke tingkat gampong/desa memiliki tugas pokok masing-masing. Di tingkat pusat dibentuk Kelompok Kerja (Pokja) dan Tim Asistensi GSI. Di tingkat kabupaten dibentuk Pokja Gerakan Sayang Ibu, diketuai bupati. Di tingkat kecamatan dibentuk Satuan Tugas (Satgas) Sayang Ibu, diketuai camat. Di tingkat desa/kelurahan dibentuk Satgas Sayang Ibu, diketuai kepala desa/ keuchik/ Tuha Peut. Diangkat dua ketua pelaksana, sekretaris, dan anggota-anggota. Tugas pokok mereka adalah menghimpun data tentang ibu hamil dan bersalin, memberikan penyuluhan, dan mengumpulkan dana untuk "ambulans desa" serta GSI merupakan suatu gerakan yang dilaksanakan dalam upaya membantu salah satu program pemerintah untuk peningkatan kualitas hidup perempuan melalui berbagai kegiatan yang berdampak terhadap upaya penurunan angka kematian ibu karena hamil, melahirkan, dan nifas.

Berikut ini adalah serangkaian kegiatan yang telah dijalankan di Gampong Tibang terkait dengan Gerakan Sayang Ibu (GSI) dengan perolehan nilai sangat baik (berdasarkan penuturan tim juri tingkat kota, Baddrunisa):

1. Pembentukan Satgas GSI yang diketuai oelh Keuchik yang melibatkan semua unsure di Gampong seperti Bidan Desa, imam Desa, Tokoh Masyarakat, TP-PKK, perangkat Gampong dan Kader Posyandu [Keputusan Gampong Tibang Nomor 25 Tahun 2011] ;

2. Penempatan Bidan Desa;

3. Pengorganisasian ambulance gampong yang dikuatkan dengan Surat Keputusan Keuchik [Keputusan Gampong Tibang Nomor 28 Tahun 2011];

4. Pengorganisasian donor darah yang dikuatkan dengan Surat Keputusan Keuchik [Keputusan Gampong Tibang Nomor 30 Tahun 2011];

5. Tersediannya Dana Sosial Ibu Bersalin (Dasolin) dan bantuan Pemerintah Aceh yang sangat besar dengan Program Jaminan Kesehatan Aceh untuk semua warga Aceh;

6. Tersedianya Data IBu Hamil dan Bersalin;

7. Sampai dengan saat ini berdasrkan pendataan yang telah dilakukan oleh kader GSI bidan desa dan kader dasawisma, Jumlah Ibu Hamil tahun 2009 sebanyak 22 jiwa. Tahun 201015 jiwa dan sampai dnegan Bulan September 2011 sebanyak 16 jiwa, dengan angka kematian IBu Hamil, melahirkan dan bayi sebanyak 0 persen atau nihil;

8. Tersedianya Polindes dan Pustu di Gampong Tibang sehingga memudahkan akses pertolongan pertama pada Ibu Hamil dan Melahirkan. 
Dari data yang tertuang dalam Laporan Geuchik Gampong Tibang (Ketua Satgas GSI) Tahun 2011, peneliti kemudian melakukan verifikasi di lapangan dan hasilnya ternyata cukup presisi. Berikut dokumentasi yang dapat peneliti tampilkan:
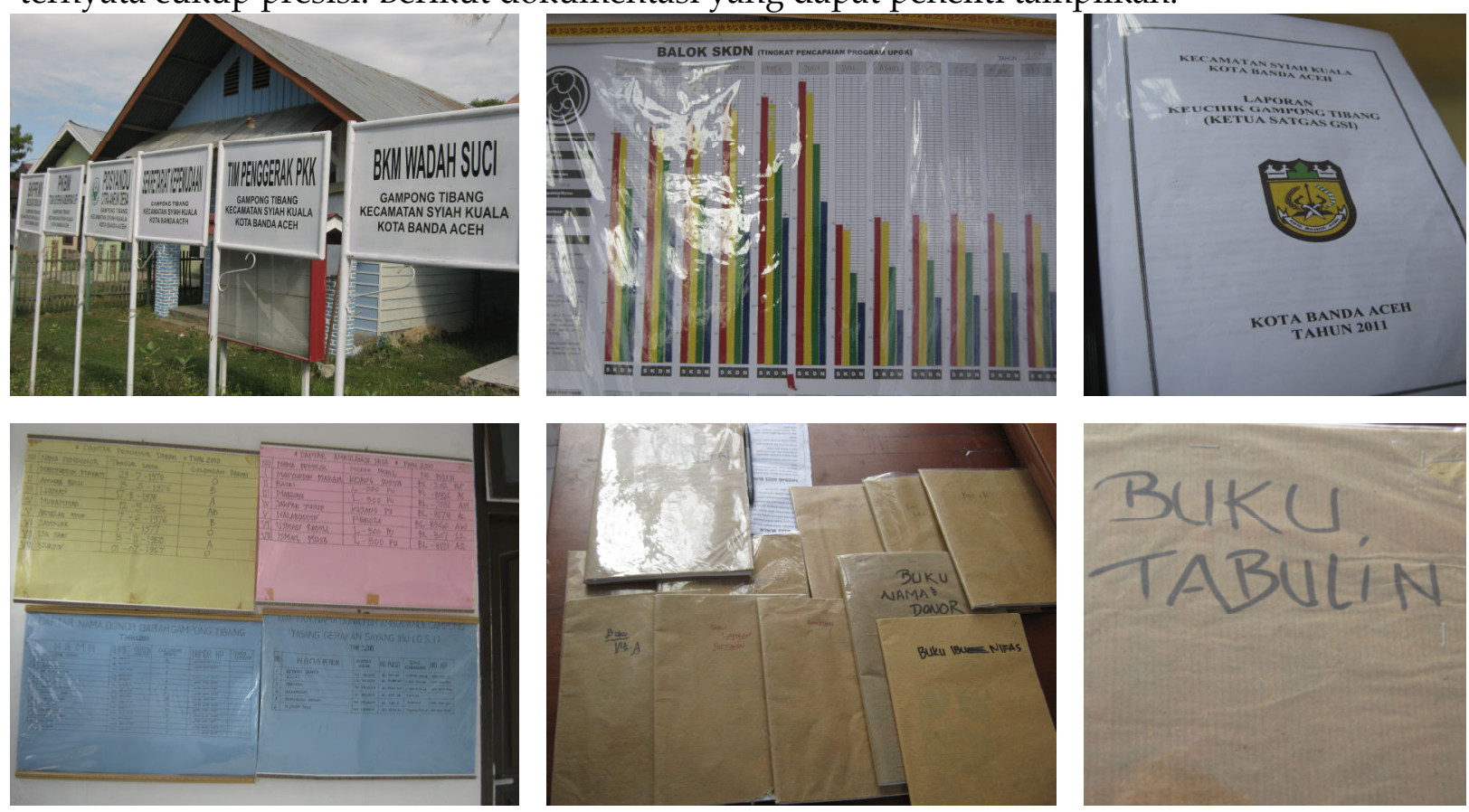

Terkait dengan pendanaan program ini diperoleh dari dana mandiri yang dihimpun oleh masyarakat melalui tabulin maupun sebagian juga diperolh dari kas gampong alokasi APBG. Sebenarnya program ini sendiri tidak menyedot dana yang relative besar karena sifantanya yang lebih brupa pengorganisasian. Selebihnya menyangkut penyuluhan, pengembangan kapasitas kader, peningkatan gizi, dana persalinan, dan teknis kesehatan lainnya di-cover oleh unit-unit terkait seperti puskesmas di bawah dinas kesehatan. Sedangkan jaminan kesehatan, diperoleh dari propinsi dalam format JKA dan sekarang disebut dengan JKRA (Jaminan Kesehatan rakyat Aceh) atau KIS/JKN.

\subsubsection{TAHAP EVALUASI}

Untuk memastikan Program GSI dipraktikkan secara baik dimasing-masing gampong/desa di tingkat kabupaten/kota maupun propinsi di seluruh Indonesia, Kementerian pemberdayaan Perempuan kemudian menginisiasi agenda turunan GSI berupa perlombaan evaluasi pelaksanaan GSI secara regular setiap tahunnya antar desa/gampong seluruh Indonesia. Pada tahap pertama perlombaan akan menghasilkan 3 juara yang akan dikirim ke tingkat propinsi, kemudian di tingkat propinsi akan diperoleh 3 juara kembali, dan barulah para juara dari masing-masing propinsi tersebut diadu di level nasional.

Setidaknya ada sejumlah motif di balik penyelenggaraan lomba ini. Pertama, motifnya adalah peningkatan kualitas competitiveness yang dibangun di antara gampong/desa; Kedua, penghargaan dan pencitraan (di media) diharapkan menjadi daya tarik/magnet (achievement) yang kuat bagi desa/gampong untuk melaksanakan program dengan baik; Ketiga, selain penghargaan simbolik pemerintah juga ingin 
menjadikan insentif material sebagai daya dorong yang efektif. Walau pun oleh pegiat GSI Tibang faktor ini tidak sepenuhnya berlaku karena nominal insentif yang terbilang kecil: Rp 5 Juta sebagai juara 1 tingkat kota dan Rp 3 Juta sebagai juara 3; Keempat, lomba secara tidak langusng juga dijadikan ajang evalusasi secara berkala pelaksaaan GSI (akuntabilitas vertical baik teknis administrative-maupun substantif; Kelima, momentum lomba adalah sarana efikatif terjalinnya komunikasi antara pemangku jabatan dengan masyarakat di level grass-root secara kontinum. Berikut ini adalah tabel tujuan pencanangan lomba GSI yang secara resmi di-release oleh Kementerian Pemberdayaan Perempuan:

\begin{tabular}{|c|l|}
\hline TUJUAN: \\
\hline Umum & Meningkatkan jumlah dan kualitas 'Kecamatan Sayang Ibu' \\
\hline Khusus & $\begin{array}{r}\text { • Mengetahui pelaksanaan revitalisasi GSI di desa dan keluarahan } \\
\text { • Mengetahui pelaksanaan revitalisasi GSI di kecamatan }\end{array}$ \\
& $\begin{array}{r}\text { - Mengetahui pelaksanaan dan revitalisasi GSI di kabupaten/kota } \\
\text { kabupaten/kota, propinsi }\end{array}$ \\
\hline Adapun kriteria perlombaan yang ditetapkan adalah sebagai berikut: \\
\hline Kriteria Desa Siap, Antar, Jaga (Siaga) \\
\hline $\begin{array}{c}\text { Desa/kelurahan siap, antar, jaga (siaga) adalahh desa/kelurahan yang } \\
\text { melaksanakan/menjalankan program GSI dan mempunyai/melaksanakan } \\
\text { langkah sebagai berikut: }\end{array}$ \\
\hline 1. & $\begin{array}{l}\text { Mempunyai SK tentang Satgas revitalisasi GSI Desa/Kelurahan } \\
\text { termasuk rencana kerja Satgas tersebut }\end{array}$ \\
\hline 2. & Mempunyai data dan peta bumi yang akurat dan selalu diperbarui \\
\hline 3. & Telah terbentuknya pengorganisasian tabulin/dasolin \\
\hline 4. & Telah terbentuknya pengorganisasian ambulan desa \\
\hline 5. & Telah terbentuknya pengorganisasian donor darah desa \\
\hline 6. & $\begin{array}{l}\text { Telah terbentuknya pengorganisasian kemitraan dukun bayi dengan } \\
\text { bidan }\end{array}$ \\
\hline 7. & $\begin{array}{l}\text { Telah terbentuknya pengorganisasian penghubung/liason (kader } \\
\text { penghubung) }\end{array}$ \\
\hline 8. & Adanya mekanisme/tata cara rujukan \\
\hline 9. & Adanya pengorganisasian: suami siaga, warga siaga, bidan siaga \\
\hline 10. & Adanya/telah terbentuknya 'Pondok Sayang Ibu' \\
\hline 11. & $\begin{array}{l}\text { Terlaksananya penyuluhan kepada tokoh masyarakat, tokoh agama, } \\
\text { keluarga, suami, dan ibu hamil tentang peningkatan kualitas hidup } \\
\text { perempuan, pencegahan kematian ibu, kematian bayi, asi eksklusif, } \\
\text { kesehatan reproduksi dan wajib belajar bagi perempuan }\end{array}$ \\
\hline 12. & Tersedianya/terlaksananya pencatatan dan pelaporan \\
\hline
\end{tabular}

\subsubsection{HASIL YANG DICAPAI}

Hasil yang dicapai dari program GSI di Gampong Tibang memang dapat dikatakan menggembirakan, betapa tidak selama 5 tahun terakhir angka kematian ibu 
(AKI) dan angka kematian bayi (AKB) berada pada derajat terendah yakni nihil. Walau pun angka statistic menunjukkan hasil yang positif namun refleksi kritis tetap perlu dilakukan. Berdasarkan wawancara dan FGD yang dilakukan selama riset lapangan dilakukan, poin-poin penting yang perlu memperoleh perhatian adalah sebagai berikut:

1. Badrunnisa selaku Kepala Kantor Pemberdayaan Perempuan, Kota Banda Aceh, secara terbuka mengutarakan bahwa Banda Aceh sebenarnya tidak dapat dijadikan tolok ukur yang tepat atas keberhasilan program GSI khususnya di lingkup propinsi. Baddrunisa menjelaskan, ada perbedaan konteks sosialmasyarakat dan pemerintahan yang kontras antara Banda Aceh dengan kabupaten lain. Banda Aceh pasca tsunami dan konflik separatis, memperoleh perhatian besar baik dari pemerintah pusat, lembaga internasional, lembaga donor, dan juga NGO yang berkembang sangat pesat.

Media dan kultur akademik di Banda Aceh juga terbilang baik. Secara historic, Banda Aceh adalah pusat peradaban Islam di semenanjung Malaka. Kekhasan konteks ini menurut Baddrunisa tidak dapat diabaikan. Ia menambahkan, faktor penjelas utama keberhasilan rendahnya AKI dan AKB Gampong Tibang secara khususnya dan Banda Aceh keseluruhan adalah tingginya angka literasi masyarakat serta tersedianya fasilitas, sarana-prasarana, dan SDM penunjang yang memadai. Ia tak lupa mengingatkan bahwa "angka partisipasi perempuan dalam pembangunan" Kota Banda Aceh berada pada rating atas di Indonesia. Banda Aceh memiliki Musrena dan Balai Inong yang tidak dimiliki oleh kabupaten/kota lainnya. Pada titik ini, Baddrunisa sebagai punggawa GSI di tingkat kota menyadari bahwa GSI di kotanya lebih berfungsi sebagai sarana assessment dan pemberian insentif secara berkala - berbeda dengan peran GSI di daerah-daerah terpencil yang benar-benar harus melakukan mainstreaming, advokasi, penyadaran, dan upaya-upaya serius agar masyarakat memberikan prioritas pada isu penurunan AKI dan AKB. Data berikut ini agaknya mengafirmasi argument dari Baddrunisa:

Jumlah Klinik KB Berdasarakan Status Kepemilikan Kota Banda Aceh Tahun 2010

\begin{tabular}{|c|c|c|c|c|}
\hline No & $\begin{array}{c}\text { Kecamatani } \\
\text { District }\end{array}$ & $\begin{array}{l}\text { Megeriv } \\
\text { Pubinc }\end{array}$ & $\begin{array}{c}\text { Suvastal } \\
\text { Prwate }\end{array}$ & $\begin{array}{l}\text { ABRU } \\
\text { Mintary }\end{array}$ \\
\hline (1) & (2) & (3) & (4) & (5) \\
\hline 1 & Meuraxa & 6 & 1 & $\circ$ \\
\hline 2 & Jaya Baru & 6 & 3 & 1 \\
\hline 3 & Banda Raya & 4 & 1 & $\circ$ \\
\hline 4 & Baiturrahman & 3 & 3 & $\circ$ \\
\hline 5 & Lueng Bata & 3 & 2 & 。 \\
\hline 6 & Kuta Alam & 6 & 4 & 1 \\
\hline 7 & Kuta Raja & 3 & $\circ$ & $\circ$ \\
\hline 8 & Syiah Kuala & 5 & 4 & $\circ$ \\
\hline 9 & Ulee Kareng & 3 & 5 & $\circ$ \\
\hline & $\begin{array}{c}\text { Jumlah/Total } \\
\text { 2010 } \\
2009 \\
2008\end{array}$ & $\begin{array}{l}39 \\
32 \\
31\end{array}$ & $\begin{array}{l}23 \\
19 \\
18\end{array}$ & $\begin{array}{l}2 \\
3 \\
3\end{array}$ \\
\hline
\end{tabular}

Banyaknya Kelahiran menurut Penolong Kelahiran di Kota Banda Aceh, 2006-2009 [kiri]; 
Jumlah Ibu Hamil, Melakukan Kunjungan K1, K4, dan Mendapat tablet Zat Besi (Fe) di Kota Banda Aceh Tahun 2006-2010 [kanan]

\begin{tabular}{|c|c|c|c|c|}
\hline Tahun & $\begin{array}{c}\text { Tenaga } \\
\text { Kesehatan1) }\end{array}$ & $\begin{array}{l}\text { Non Tenaga } \\
\text { Kesehatan }{ }^{2)}\end{array}$ & Jumlah & $\begin{array}{c}\text { Persentase } \\
\text { Tenaga } \\
\text { Kesehatan } \\
\text { K (2) / K (4) x } \\
100 \% 1 \text { digit }\end{array}$ \\
\hline (1) & (2) & (3) & (4) & (5) \\
\hline 2006 & 3822 & 0 & 3822 & 100 \\
\hline 2007 & 3530 & 0 & 3530 & 100 \\
\hline 2008 & 4060 & 0 & 4060 & 100 \\
\hline 2009 & 4148 & 0 & 4148 & 100 \\
\hline \multicolumn{5}{|c|}{$\begin{array}{l}\text { Sumber : Dinas Kesehatan Kota Banda Aceh } \\
\text { Source: Health Office of Banda Aceh Municipality }\end{array}$} \\
\hline \multicolumn{5}{|l|}{ Catatan: } \\
\hline $\begin{array}{l}\text { 1) Terdiri c } \\
\text { 2) Dukun }\end{array}$ & dan bid & & & \\
\hline
\end{tabular}

\begin{tabular}{|c|c|c|c|c|c|c|}
\hline Tahun & $\begin{array}{c}\text { Jumlah } \\
\text { Ibu } \\
\text { Hamil }\end{array}$ & $\begin{array}{c}\text { Melakukan } \\
\text { Kunjungan } \\
\text { K1 }\end{array}$ & $\begin{array}{c}\text { Melakukan } \\
\text { Kunjungan } \\
\text { K4 }\end{array}$ & $\begin{array}{l}\text { Jumlah Ibu } \\
\text { Hami Risti/ } \\
\text { Komplikasi }\end{array}$ & $\begin{array}{c}\text { Mendapat } \\
\text { Zat Besi } \\
\text { (Fe1) }\end{array}$ & $\begin{array}{c}\text { Mendapat } \\
\text { Zat Besi } \\
\text { (Fe3) }\end{array}$ \\
\hline (1) & (2) & (3) & (4) & (5) & (6) & (7) \\
\hline 2006 & 5.740 & 4.949 & 4.423 & 1.148 & 4.844 & 4.355 \\
\hline 2007 & 5.379 & 4.691 & 4.118 & 1.073 & 3.885 & 3.324 \\
\hline 2008 & 5.176 & 5.043 & 4.366 & 368 & 3.139 & 2.720 \\
\hline 2009 & 5.274 & 5.060 & 4.441 & 8 & 5.060 & 4.410 \\
\hline 2010 & 5.400 & 5.159 & 4.710 & 435 & 5.052 & 4.619 \\
\hline
\end{tabular}

2. Poin berlainan yang juga tak kalah penting disampaikan oleh Wakil Walikota Illiza Saaduddin Djamal saat penelitian, dan sekarang sudah menjadi Walikota Banda Aceh menggantikan Alm. Mawardi Nurdin, Ia mengingatkan, walaupun penurunan AKI dan AKB adalah tujuan utama dari GSI, namun sebaiknya pengukuran keberhasilan tak hanya dari dua aspek tersebut. GSI secara tidak langsung juga merupakan bentuk pendidikan gender bagi masyarakat. GSI menjadi ajang penyadaran bahwa problem yang selama ini diidentifikasi sebagai problem perempuan sebenarnya juga merupakan problem laki-laki, problem keluarga, problem kolektif di lingkungan sekitar, bahkan negara. Serta satu hal yang juga perlu dicatat, GSI terlepas dari isu persalinan adalah sebuah upaya memantapkan modal sosial di lingkup masyarakat desa/gampong yang kini mulai terguras dan terganti dengan individualitas para warganya.

3. Syaiful (Aktivis LPPM, LSM Aceh) dan Indri (Aktivis LSM, LSM Aceh) kurang lebih se-Aceh dalam menilai GSI bahwa pada sejumlah kasus memang dapat dibaca positif dalam meningkatkan kesadaran masyarakat, namun demikian, evalusasi yang diformat dalam bentuk perlombaan justru bisa menjadi pisau bermata dua. Maksudnya, di satu sisi sebagai insentif daya dorong namun di sisi lain menjadi perangkap politik citra yang artificial. Keduanya menengarai tidak sedikit desa/gampong yang melaksanakan GSI berorientasikan semata-mata lomba dan pemberitaan media. Hal ini lumrah dipahami karena criteria penilaian yang ditetapkan oleh kementerian pemberdayaan perempuan sangat bercorak kuantitaif dan formalistic, seperti: keberadaan regulasi desa yang mengatur tabulin, pendonor, ambulans, dll, yang jelas mudah dimanipulasi. Padahal menurut mereka keberhasilan sesungguhnya dari GSI sesungguhnya tercermin di 
internal keluarga. Apakah sudah ada pembagian peran antara laki-laki dan perempuan yang setara dalam persoalan kehamilan, persalinan, dan juga pengasuhan anak.

\subsubsection{Bekerjanya Seff Governing Community sebagai Faktor Determinan Penjelas Keberhasilan: Mengharap Titik Balik, Membangun Daerah dari Gampong/Desa}

Self governing community (SGC) adalah kemampuan suatu komunitas/ kelompok/warga masyarakat di suatu wilayah tertentu dalam menjalankan tata kelola pemerintahannya sendiri secara mandiri dan umumnya otonom, baik secara positif sebagai penyokong, pelengkap, maupun alternative dari governance by government, atau pun negatif dalam artian kontra negara sebagai substitusi. SGC juga merupakan bukti bahwa bahwa proses pengelolaan urusan-urusan bersama/collective dalam ruang publik tidak hanya dilakukan oleh negara, sebagai public agency, melainkan dilakukan pula oleh community. Dan karenanya, community governance kemudian diidentikan dengan pemberdayaan komunitas, karena berhasil menjadi penjelas di balik keberhasilan pertumbuhan, pemerataan ekonomi, dan pengentasan kemiskinan di sebuah komunitas. ${ }^{2}$ Hal itu terbukti dengan adanya mekanisme kerja kelembagaan gampong pada level terbawah sampai eksistensi kesultanan pada derajat tertinggi. Mekanisme ini berperan mengatur hubungan masyarakat dan negara dengan menempatkan Islam sebagai sumber hukum berikut tokoh masyarakat sebagai pemangku kepentingan utama dalam menjaga tertib sosial di sana.

Pada level gampong, misalnya, forum pertemuan di meununasah (masjid) yang dipimpin oleh imuem meunasah dan tokoh alim-ulama merupakan mekanisme pengambilan keputusan tertinggi pada masyarakat Aceh. Mekanisme pengambilan keputusan melalui proses yang sama juga dilakukan pada tingkat pemerintahan yang lebih tinggi, yaitu: Mukim, Uleebalang, Sagoe dan Kesultanan. Dalam setiap level pemerintahan tersebut pimpinan agama atau alim-ulama diposisikan pada tempat yang tertinggi, tidak hanya memimpin umat akan tetapi juga memimpin pemerintahan. Sultan di sini termasuk yang memainkan peran rangkap tersebut.

Melengkapi keduanya, ada pula kepemimpinan informal lain seperti yakni Pak Geuchik (Kepala Desa), ataupun Tuha Peut (Empat Petua Kampung) ataupun juga Tengku Imeum (Imam Menasah Kampung). Pola pe-tokoh-an atau pemimpin tersebut merupakan hasil pemilihan dan verifikasi sosial dalam bentuk pengakuan kemampuan tokoh tersebut yang dilakukan oleh masyarakat melalui observasi yang bertahun-tahun terhadap tindak tanduk, kelakukan, akhlaq, kejujuran dan kemampuan serta kearifan mereka, yang diamati dan dinilai secara langsung oleh masyarakat kampungnya dan dianggap mampu dan sesuai dengan pola kepimpinan yang diinginkan masyarakatnya.

2 Sejumlah poin yang mempengaruhi eksistensi (prasyarat) SGC secara umum adalah sebagai berikut: adanya 1) (Model) Kepemimpinan; 2) (Model) Pengambilan keputusan bersama; 3) Norma atau aturan; 4) Sistem nilai (etik-normatif); 5) (Model dan bentuk-bentuk) Pelembagaan masyarakat; 6) (Model) Penyelesaian konflik/krisis; 7) Mekanisme Pengelolaan sumberdaya bersama; 8) (model) Pembagaian kerja/peran; 9) (Model) Solidaritas dan jaminan sosial; 10) Sistem transaksional (ekonomikal); 11) Sistem hak milik; 12) Sistem religi dan mistifikasi/mitos; 134) Mekanisme tranfer pengetahuan; 14) Sistem bahasa 
Menjaga SGC mampu menjelaskan betapa persoalan-persoalan personal dan privat dapat dikonversi dengan baik menjadi persoalan kolektif baik itu keluarga, lingkungan, bahkan masyarakat; sebagai penjelas pembangunan di level komunitas. Hal tersebut misalnya tercermin pada kasus persalinan. Dalam masyarakat modern, tidak ada sebuah kewajiban maupun tuntutan bagi orang lain untuk terlibat secara aktif dalam proses penangan persalinan yang tidak memiliki ikatan formal dengannya. Melalui SGC yang diterjemahkan dalam format GSI, kepeduliaan itu berwujud jaminan sosial swadaya: tabulin, ambulan desa, atau pun kesiap-siagaan pendonor darah di kala darurat. SGC sendiri secara tidak langsung sebenarnya merupakan instrument yang efektif dan efikatif dalam meredam konflik baik horizontal maupun vertical. Dengan begitu sebenarnya ulasan mengenai GSI khususnya di Tibang mengajak kita untuk memikirkan kembali vitalitas gampong/desa sebagai sentrum pembangunan.

\section{PENUTUP}

Artikel Penelitian tentang GSI yang dilakukan pada tahun 2010 ini membuktikan kepada kita bahwa ketika gerakan perubahan dimulai dari gampong membuktikan sebuah bentuk pola pengembangan masyarakat dalam bentuk pengorganisasian masyarakat. Apalagi ketika pola pemberdayaan itu tumbuh dari pola kepemimpinan yang digerakkan oleh aktor kepemipinan terkecil dilevel gampong, berikut beberapa poin penting untuk menjadi sebuah Lesson learn dari beberapa poin pembelajaran yang dapat diangkat dari pelaksanaan GSI di Gampong Tibang adalah sebagai berikut:

1. Keberhasilan program sebagaimana disampaikan sebagian besar narasumber merupakan pencapaian kolektif multi-stake holder baik itu masyarakat, pemangku kebijakan, organisasi kemasyarakatan, media, dsb. Pada titik ini, sinergitas kemudian menjadi faktor yang determinan.

2. Keberhasilan GSI Tibang adalah bukti bahwa pendekatan holistic diperlukan dalam mengidentifikasi, merumuskan, merancang, melaksanakan, serta mengevaluasi program di tengah masyarakat. Rendahnya AKI dan AKB, selain distimulus oleh GSI, utamanya lebih karena tingginya political will seorang kepala daerah, sinergi multi-stake holder, regulasi yang memadai, kepemimpinan di level local, kuatnya modalitas sosial, tingginya tingkat literasi masyarakat, kesadaran gender, ketersediaan sarana prasarana, dan sebagainya yang sedemikian kompleks. Dengan demikian membayangkan AKI dan AKB akan menurun secara signifikan hanya melalui GSI sangatlah tidak relevan.

3. Faktor khas dari pelaksanaan GSI di Banda Aceh secara umum adalah operasionalitasnya yang berada di unit gampong dimana modalitas sosial memainkan peranan penting. Pada kasus GSI di Tibang ini, kita dapat mengamati bertautanya format kepemerintahan formal dan informal secara mutualistik dalam relasi komplementatif.

\section{REFERENSI}

Ahmed, Leila. 1992. Women and Gender in Islam. New Haven: Yale 
Berkey, Jonathan. 1992. "Women and Educatio: The Transmission of Knowledge in Medieval Period: A Social History of Islamic Education. Princeton: Princeton University Press.

BYRNE, Bridget and LAIER, Julie Koch.1996. National Machineries for Women in Development: Experiences, Lessons and Strategies for Institutionalzing Gender in Development, Policy and Planning Bridge Report No. 36.

Fakih, Mansour .1998. Analisa Gender. Gramedia: Jakarta.

Hasbullah, Jaousairi. 2006. Social Capital: Menuju Keunggulan Budaya Manusia Indonesia. Jakarta: MR-United Press.

Ibrahim, Linda D. 2006. Kehidupan Berorganisasi Sebagai Modal Sosial Komunitas Jakarta: Fakultas Ilmu Sosial dan Ilmu Politik Universitas Indonesia.

Jhon Field. 2005. Modal Sosial. Medan : Media Perintis.

Masrizal, 2015, Pengendalian Masalah Sosial Melalui Kearifan Lokal, Banda Aceh: Syiah Kuala University Press

PAKPAHAN, Dameria. 1996. Women and Culture in Indonesia: Images in Religion, Customary Law in the State Asia Pacific Women's Studies Journal 6:7-

\section{Internet:}

Rahima,2005,http://microdata.bps.go.id/mikrodata/index.php/catalog/SUSENAS\#_ $\mathrm{r}=\&$ collection $=\&$ country $=\&$ dtype $=\&$ from $=1971 \&$ page $=1 \& \mathrm{ps}=\&$ sk $=\&$ sort_by $=$ proddate\&sort_order $=$ desc\&to $=2010 \&$ topic $=\& v i e w=s \& v k$

http://www.bandaacehkota.go.id/dalam http://sipbm.bandaacehkota.go.id/publicgrap-asi.html http://igi.fisipol.ugm.ac.id/index.php/en/good-practice-database 